\title{
SYNERGISM OF CEPHALOSPORINS AT SUBINHIBITORY CONCENTRATIONS AND POLYMORPHONUCLEAR LEUKOCYTES ON PHAGOCYTIC KILLING OF ESCHERICHIA COLI AND ITS MODE OF ACTION
}

\author{
Yuji Watanabe, Shuichi Tawara, Yasuhiro Mine and Hiroyuki Kikuchi \\ Research Laboratories, Fujisawa Pharmaceutical Co., Ltd., \\ 2-1-6 Kashima, Yodogawa-ku, Osaka 532, Japan \\ Sachiko Goto and Shogo Kuwahara \\ Department of Microbiology, Toho University, School of Medicine, \\ 5-21-16 Ohmori Nishi, Ohta-ku, Tokyo 143, Japan
}

(Received for publication September 18, 1985)

\begin{abstract}
The interactions between subinhibitory concentrations of cephalosporins and polymorphonuclear leukocytes in the killing of a strain of Escherichia coli are described and an attempt is made to define the responsible mechanism. Ceftizoxime was the most potent agent tested. Pretreatment of the $E$. coli strain with subinhibitory concentrations of ceftizoxime increased the susceptibility to both; phagocytic killing activity of the polymorphonuclear leukocytes and bactericidal activities of the oxygen metabolites and the granule extracts. A most interesting result was the increased susceptibility of the ceftizoxime-treated $E$. coli to killing by $\beta$-glucuronidase which normally is not bactericidal. It is suggested that the augmented killing could be due to bacteriolysis by $\beta$-glucuronidase.
\end{abstract}

There have been many reports on the positive and negative interactions between antimicrobial agents and host defense factors ${ }^{1 \sim \theta)}$, and the desirable properties of an antibiotic would be synergism and the absence of antagonistic effects on the host immune system. Since the actual time of contact of bacteria with an antibiotic at levels higher than the minimum inhibitory concentration (MIC) may be relatively short in the blood and the sites of infection, subinhibitory concentrations (sub-MICs) play an important role in the efficacy of antibiotics in vivo. LORIAN reviewed the effects of antibiotics at sub-MICs ${ }^{7)}$. We also showed in an earlier study that sub-MICs of carbenicillin and nocardicin A enhanced the phagocytic killing of Pseudomonas aeruginosa by rabbit polymorphonuclear leukocytes $(\mathrm{PMNs})^{8,9)}$. The synergism of some of the new cephalosporins with potent antibacterial activities and PMNs should also be evaluated in detail. This study was designed to evaluate the synergism of representative cephalosporins at sub-MICs and PMNs on the phagocytic killing of Escherichia coli and the mode of action of this synergism.

\section{Materials and Methods}

Bacterial Strain

Clinically isolated E. coli strain No. 59 is susceptible to $\beta$-lactams and is highly resistant to serum bactericidal activity.

Antibiotics

Ceftizoxime (Fujisawa Pharmaceutical Co., Ltd., Osaka, Japan), cefazolin (Fujisawa Pharmaceutical Co., Ltd.), cefotiam (Takeda Chemical Ind., Ltd., Osaka, Japan), ceftazidime (Glaxo Res., Ltd., 
Greenford, UK), cefotaxime (Hoechst-Roussel, West Germany), latamoxef (Shionogi \& Co., Ltd., Osaka, Japan), cefoperazone (Toyama Chemical Co., Ltd., Tokyo, Japan) and cefmenoxime (Takeda Chemical Ind., Ltd.).

\section{Reagents}

Isopropylthio-D-galactopyranoside (IPTG), $\beta$-glucuronidase (respective specific activities: 18,000 and $550 \mathrm{u} / \mathrm{mg}$ ), lysozyme, acid phosphatase and phospholipase $\mathrm{A}_{2}$ (Sigma Chemical Co., St. Louis, Mo.), $o$-nitrophenyl- $\beta$-D-galactopyranoside (ONPG) and sodium D-glucuronate (Nakarai Chemical Co., Kyoto, Japan), and (DL + meso)-2,6-diamino[ $\left[{ }^{3} \mathrm{H}\right]$ pimelic acid $\left(\left[{ }^{3} \mathrm{H}\right] \mathrm{DAP}\right.$, specific activity: 574 $\mathrm{mCi} / \mathrm{mmol}$, Amersham International, UK). The above enzymes were used without further purification.

Determination of MICs

Broth dilution MICs were determined with overnight broth culture of E. coli No. 59 in MuellerHinton broth (Difco). The culture was diluted with this broth to give an inoculum of $10^{8} \mathrm{cfu} / \mathrm{ml}$. Test tube containing $9 \mathrm{ml}$ of the culture conditions and $1 \mathrm{ml}$ of serially two-fold dilutions of the antibiotics were incubated at $37^{\circ} \mathrm{C}$ for 18 hours. After incubation, the lowest antibiotic concentration inhibiting visual bacterial growth was regarded as the MIC. The MICs of the antibiotics used were as follows: $1.56 \mu \mathrm{g} / \mathrm{ml}$ for cefazolin, $0.2 \mu \mathrm{g} / \mathrm{ml}$ for cefotiam, $0.1 \mu \mathrm{g} / \mathrm{ml}$ for ceftazidime, ceftizoxime and cefoperazone, $0.39 \mu \mathrm{g} / \mathrm{ml}$ for latamoxef, $0.05 \mu \mathrm{g} / \mathrm{ml}$ for cefmenoxime, and $0.025 \mu \mathrm{g} / \mathrm{ml}$ for cefotaxime.

\section{Ceftizoxime-resistant Strain}

E. coli No. 59 was subcultured 30 times in Mueller-Hinton broth containing serially increased doses of ceftizoxime. The MIC of ceftizoxime for the resultant ceftizoxime-resistant E. coli No. 59R1 was $6.25 \mu \mathrm{g} / \mathrm{ml}$.

\section{Pretreatment of $E$. coli with Ceftizoxime}

Ceftizoxime-pretreated $E$. coli were used in the experiments except those shown in Fig. 1. The culture of E. coli No. 59 incubated in Mueller-Hinton broth at $37^{\circ} \mathrm{C}$ for 30 minutes was mixed with ceftizoxime at sub-MICs and incubated for 2 hours. Then, the $E$. coli was washed by centrifugation to remove the ceftizoxime and used for the experiments.

\section{Preparation of PMNs and Granule Extracts}

Rabbit PMNs were obtained from the peritoneal cavity of rabbits injected with glycogen by the CoHN method ${ }^{10)}$. Human PMNs were purified by the Boyum method ${ }^{11)}$ using sequential sedimentation with dextran and Ficoll-Hypaque (Pharmacia Fine Chemicals AB, Uppsala, Sweden). The final PMN suspensions contained more than $95 \%$ PMNs. The crude granule extracts from the PMNs were prepared by the modified REST method ${ }^{12)}$ as follows: PMNs $\left(2 \times 10^{7}\right.$ cells $\left./ \mathrm{ml}\right)$ were suspended in $25 \%$ sucrose and disrupted by sonication with a ultrasonic disruptor model UR-200 (Tomy Seiko Co., Ltd., Tokyo, Japan). The undisrupted cells, nuclei and aggregated cell debris were removed by centrifugation at $126 \times g$ for 15 minutes. The crude granule extracts were precipitated by centrifugation at $20,000 \times g$ for 20 minutes.

\section{Phagocytosis and Killing}

The suboptimum conditions for PMNs to phagocytose and kill bacteria were used to observe the synergistic effect of the antibiotics. The reaction mixture comprising PMNs $\left(2 \times 10^{8} / \mathrm{ml}\right)$, E. coli No. 59 $\left(1 \times 10^{\circ} / \mathrm{ml}\right)$, autologous serum $(5 \%)$, antibiotic and $25 \mathrm{~mm} N$-2-hydroxyethylpiperazine- $N$ '-2-ethanesulfonic acid-buffered Hanks' balanced salt solution (HEPES-HBSS) was incubated with gentle shaking at $37^{\circ} \mathrm{C}$ for 2 hours. Thereafter, $50 \mu 1$ portions were plated onto brain heart infusion agar (Difco) and the colonies were counted after incubation for 24 hours.

\section{Bactericidal Test}

Equal volume $(100 \mu \mathrm{l})$ of E. coli No. $59\left(10^{3} \sim 10^{4} / \mathrm{ml}\right)$ and bactericidal materials (granule extracts, lysosomal enzymes and hydrogen peroxide and hypochlorous acid) were incubated at $37^{\circ} \mathrm{C}$ for 1 hour 
Fig. 1. Effect of sub-MICs of various cephalosporins on the phagocytic killing of $E$. coli by human PMNs. PMNs $\left(2 \times 10^{8} / \mathrm{ml}\right)$, E. coli No. $59\left(1 \times 10^{8} / \mathrm{ml}\right)$ and antibiotics were incubated at $37^{\circ} \mathrm{C}$ for 2 hours with gentle shaking and the residual viable $E$. coli were counted on agar plates. The same experiment was done 3 times and the representative results are presented in this figure.

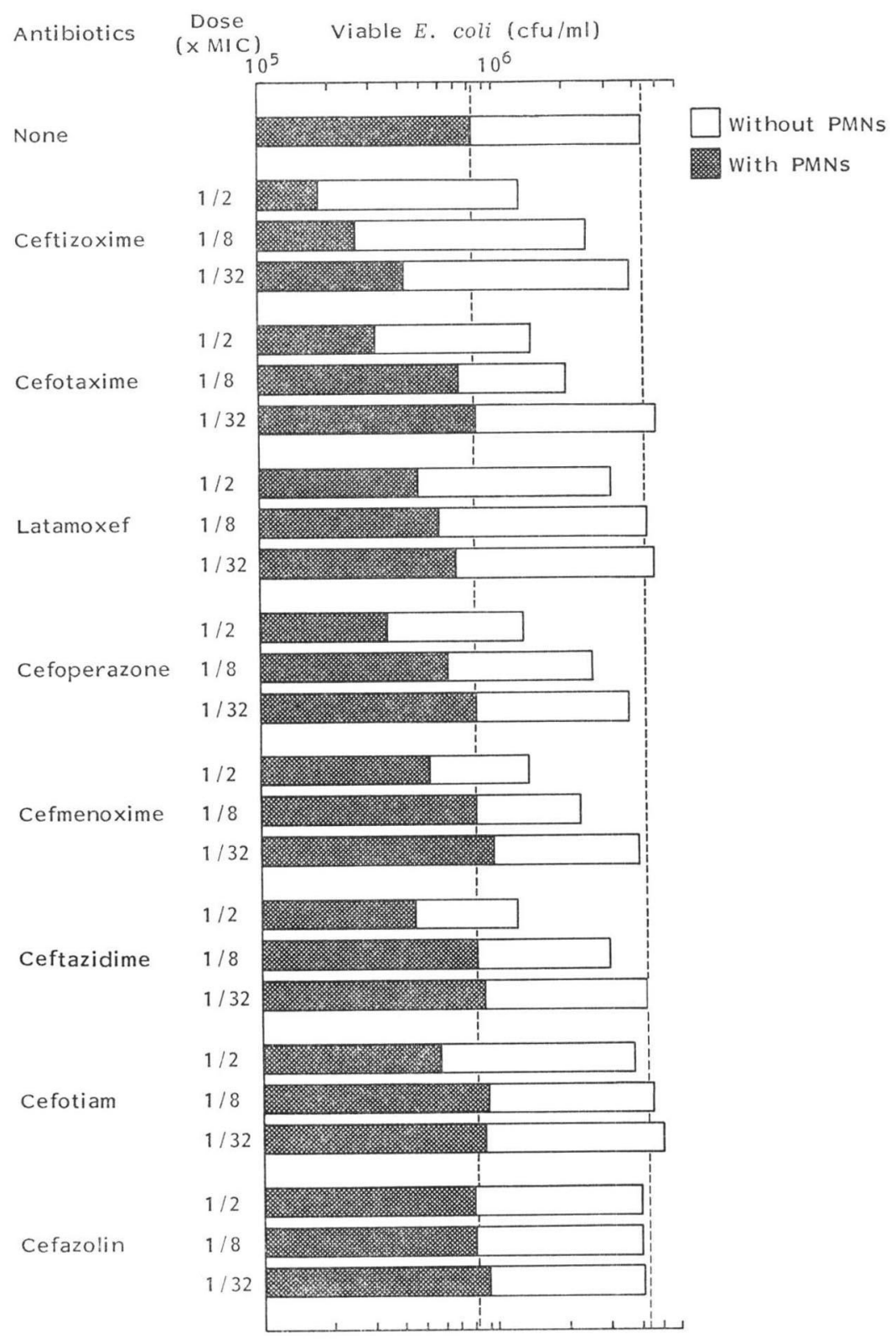

in a 96 well-microtray, and the residual viable bacteria were counted as described above. The reaction was conducted in $0.1 \mathrm{M}$ citrate buffer $(\mathrm{pH}$ 6) since intra-lysosomal $\mathrm{pH}$ was reported to be about $6^{13,14)}$. The bactericidal activity of superoxide anion $\left(\mathrm{O}_{2}^{-}\right)$was tested by a modification of the BABIOR method $^{15)}$. That is, the reaction mixture $(200 \mu \mathrm{l})$ containing E. coli $\left(4 \times 10^{5} / \mathrm{ml}\right)$, xanthine oxidase, $1.3 \mathrm{~mm}$ xanthine, $145 \mathrm{~mm} \mathrm{NaCl}$ and $100 \mathrm{~mm}$ phosphate buffer $(\mathrm{pH} 7.5)$ was incubated at $37^{\circ} \mathrm{C}$ for 1 hour and the residual viable bacteria were counted. 
Scanning Electron Microscopy

E. coli was fixed with $1.5 \%$ glutalaldehyde followed by $2 \% \mathrm{OsO}_{4}$. After dehydration with ethanol, the samples were suspended in isoamyl acetate, dried with a critical point dryer model HCP-1 (Hitachi Ltd., Tokyo, Japan), coated with platinum with a multicoater model VX-10 (Eiko Engineering Co., Tokyo, Japan) and observed with a scanning electron microscope model S-450 (Hitachi Ltd.).

Degradation of Peptidoglycan of E. coli

E. coli No. 59 cells were radioactively labeled with $10 \mu \mathrm{Ci}$ of $\left[{ }^{3} \mathrm{H}\right] \mathrm{DAP}$ per milliliter of MuellerHinton broth at $37^{\circ} \mathrm{C}$ for 1 hour, washed twice with isotope-free Mueller-Hinton broth, and incubated in isotope-free Mueller-Hinton broth at $37^{\circ} \mathrm{C}$ for 30 minutes to remove the isotope in intracellular DAP pool. The labeled cells were treated with ceftizoxime and $\beta$-glucuronidase as described above. The released radioactivity in the supernatant after centrifugation was counted, and the ratio of released radioactivity to total activity of the reaction mixture incubated with $0.4 \%$ deoxycholate at $37^{\circ} \mathrm{C}$ for 30 minutes was calculated.

Measurement of Envelope Damage

Envelope damage of $E$. coli No. 59 pretreated with ceftizoxime was determined by the following two methods: 1) The plasmid encoding TEM type $\beta$-lactamase which could not hydrolyze ceftizoxime was introduced into E. coli No. 59 by transconjugation. The resultant E. coli No. 59R2 was as susceptible to ceftizoxime as the parent strain. The transconjugant was pretreated with ceftizoxime at $1 / 16$ and $1 / 32$ the MIC and suspended in $0.1 \mathrm{M}$ citrate buffer $\left(\mathrm{pH}\right.$ 6). After incubation at $37^{\circ} \mathrm{C}$ for 30 and 60 minutes, the supernatant of half of the incubation mixture was filtrated with Millipore filter (pore size: $0.45 \mu \mathrm{m}$ ). The $\beta$-lactamase activity was determined by measuring the increase in absorbance at $500 \mathrm{~nm}$ with a spectrophotometer model 220A (Hitachi Ltd.) using a cell holder equipped with a thermostat after incubation with chromogenic cephalosporin (synthesized in our Research Laboratories). The total enzyme activity was also determined on the other half of the incubation mixture after sonication. Envelope damage was expressed as the ratio of relative $\beta$-lactamase activity to the total one. 2) E. coli No. 59 was incubated at $37^{\circ} \mathrm{C}$ for 2 hours with IPTG at the concentration of 100 $\mu \mathrm{g} / \mathrm{ml}$ to induce $\beta$-galactosidase and was pretreated with ceftizoxime at $1 / 16$ and $1 / 32$ the MIC and suspended in $0.1 \mathrm{M}$ citrate buffer ( $\mathrm{pH}$ 6). The treated $E$. coli was incubated at $37^{\circ} \mathrm{C}$ for 30 minutes with ONPG, the reaction was stopped with $1 \mathrm{M} \mathrm{Na}_{2} \mathrm{CO}_{3}$ and the absorbance at $420 \mathrm{~nm}$ was measured spectrophotometrically. Envelope damage was expressed as the ratio of relative absorbance to total absorbance in bacteria treated with toluene.

\section{Results}

Effect of Cephalosporins on Phagocytic Killing of E. coli by Human and Rabbit PMNs

Fig. 1 shows the results of a representative experiment on the effect of sub-MICs of the cephalosporins on the phagocytic killing of E. coli No. 59 by human PMNs. Ceftizoxime, cefmenoxime, cefotaxime and cefoperazone, even at $1 / 8$ the MIC, had a subinhibitory effect on the growth of $E$. coli No. 59 in the absence of the PMNs. In the presence of the PMNs, the bactericidal effect of the drugs tested, except cefotiam and cefazolin, was higher than that of either the antibiotics or the PMNs alone and ceftizoxime had the most potent bactericidal activity even at 1/32 the MIC. This tendency was reproducible. Since a similar potency was observed in the presence of rabbit PMNs and also against other strains of $E$. coli (data not shown), rabbit PMNs and ceftizoxime were used to investigate whether this synergism was based on the increased susceptibility of the ceftizoxime-damaged $E$. coli to the phagocytic killing activity of PMNs or on activation of the functions of the PMNs by ceftizoxime.

Susceptibility of Ceftizoxime-treated E. coli to Phagocytic Killing by PMNs

First, the susceptibility of the ceftizoxime-pretreated E. coli to the phagocytic killing by rabbit PMNs 
Fig. 2. Susceptibility of ceftizoxime-pretreated $E$. coli to bactericidal activity of rabbit PMNs.

E. coli No. 59 was pretreated with ceftizoxime at $1 / 4$ the MIC for 2 hours. The open symbols indicate incubation in the absence of PMNs and the closed symbols indicate incubation in the presence of PMNs.

Symbols: Untreated E. coli $(\bigcirc, \bullet)$; ceftizoximepretreated $E$. coli $(\square$, 圆).

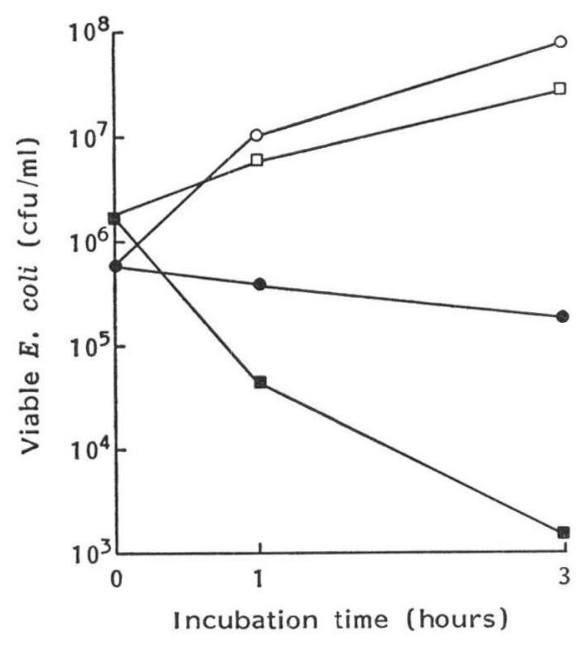

was compared to that of the untreated strain (Fig. 2). The growth speed of the $E$. coli pretreated with ceftizoxime at $1 / 4$ the MIC was similar to that of the untreated $E$. coli in the absence of the PMNs. However, the ceftizoxime-treated $E$. coli became more susceptible than the untreated $E$. coli
Fig. 3. Susceptibility of ceftizoxime-pretreated $E$. coli to bactericidal activity of granule extracts from rabbit PMNs.

E. coli No. 59 was pretreated with ceftizoxime at $1 / 4$ the MIC for 2 hours. The experiment was done in duplicate.

* Relative bacterial counts of $E$. coli treated with bactericidal materials to those of nontreated $E$. coli.

Symbols: Untreated $E$. coli ( $)$; ceftizoximepretreated E. coli $(O)$.

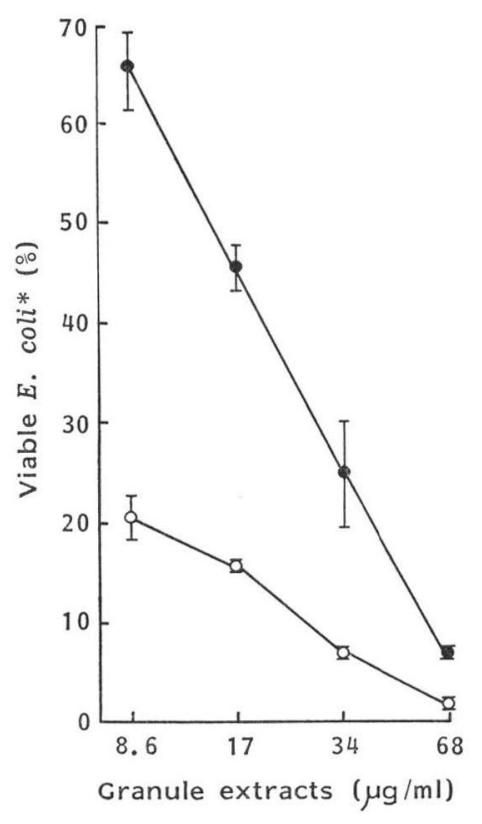

to the phagocytic killing by the PMNs. Next, to investigate the direct effect of ceftizoxime on the functions of the PMNs, rabbit PMNs were preincubated with 0.01 to $1.0 \mu \mathrm{g} / \mathrm{ml}$ of ceftizoxime at $37^{\circ} \mathrm{C}$ for 30 minutes. After removal of ceftizoxime, $\mathrm{O}_{2}^{-}$release and bactericidal activity against $E$. coli No. 59 were determined. There was no significant difference between the ceftizoxime-treated and the intact PMNs in either $\mathrm{O}_{2}^{-}$release or bactericidal activity (data not shown). These results indicate that the direct activity of ceftizoxime against $E$. coli increased the susceptibility of the organism to the phagocytic killing by PMNs.

To elucidate the cause of the increased susceptibility of the ceftizoxime-treated E. coli to the phagocytic killing activity of PMNs, the susceptibility of the ceftizoxime-treated E. coli to the killing mechanisms of PMNs was compared with that of the untreated $E$. coli. The ceftizoxime-treated $E$. coli became more susceptible than the untreated $E$. coli to the bactericidal activity of the crude granule extract used for the $\mathrm{O}_{2}$-independent bactericidal system of PMNs (Fig. 3). In an attempt to understand this phenomenon, the susceptibility of the ceftizoxime-treated $E$. coli to several lysosomal enzymes was tested. The viable cell counts of the ceftizoxime-treated $E$. coli decreased markedly in the presence of $\beta$-glucuronidase, whereas the untreated $E$. coli resisted killing by the enzyme (Fig. 4). The granule extracts used above contained $\beta$-glucuronidase at $73 \mathrm{U} / \mathrm{ml}$, the concentration at which 
Fig. 4. Killing of ceftizoxime-pretreated $E$. coli by $\beta$-glucuronidase.

E. coli No. 59 was pretreated with ceftizoxime at $1 / 4$ the MIC for 2 hours. All experiments were done in duplicate.

* Relative bacterial counts of $E$. coli treated with $\beta$-glucuronidase to those of nontreated $E$. coli.

Symbols: Untreated E. coli (๑); ceftizoximepretreated $E$. coli $(\bigcirc)$.

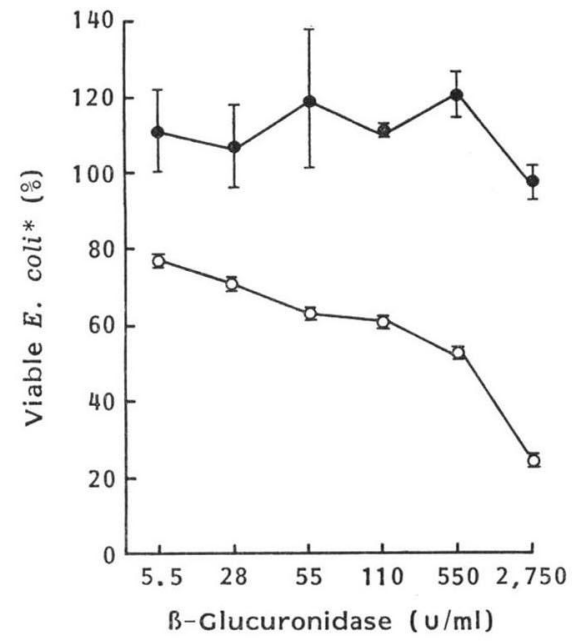

Table 1. $\beta$-Glucuronidase-specificity in killing of ceftizoxime-treated $E$. coli.

\begin{tabular}{|c|c|c|c|}
\hline \multirow{2}{*}{\multicolumn{2}{|c|}{$\beta$-Glucuronidase }} & \multicolumn{2}{|c|}{ Viable $E$. coli a $(\%)$} \\
\hline & & $\begin{array}{l}\text { Ceftizoxime- } \\
\text { treated }\end{array}$ & Untreated \\
\hline \multicolumn{2}{|c|}{$\begin{array}{l}\text { Boiled } \\
\quad\left(100^{\circ} \mathrm{C}, 5 \text { minutes }\right)^{\mathrm{b}}\end{array}$} & $101^{\mathrm{c}}$ & 107 \\
\hline \multicolumn{2}{|c|}{ Nonboiled $^{\mathrm{b}}$} & 63 & 102 \\
\hline \multicolumn{2}{|c|}{$\begin{array}{l}\text { With D-glucuronate } \\
(5 \mathrm{mg} / \mathrm{ml})^{\mathrm{b}}\end{array}$} & $97^{\mathrm{d}}$ & 109 \\
\hline \multicolumn{2}{|c|}{ Without D-glucuronate ${ }^{b}$} & 66 & 106 \\
\hline \multicolumn{2}{|c|}{$\begin{array}{l}\text { High specific activity } \\
(18,000 \mathrm{u} / \mathrm{mg})\end{array}$} & 51 & 114 \\
\hline \multicolumn{2}{|c|}{$\begin{array}{l}\text { Low specific activity } \\
\quad(550 \mathrm{U} / \mathrm{mg})\end{array}$} & 53 & 104 \\
\hline \multicolumn{4}{|c|}{$\begin{array}{l}\text { E. coli No. } 59 \text { was pretreated with ceftizoxime at } \\
1 / 4 \text { the MIC for } 2 \text { hours and treated with } \beta \text {-glu- } \\
\text { curonidase at } 275 \mathrm{U} / \mathrm{ml} \text {. All experiments were } \\
\text { done in duplicate and the average values were } \\
\text { shown. }\end{array}$} \\
\hline & $\begin{array}{l}\text { See legend to Fig. } \\
\beta \text {-Glucuronidase } \\
\text { u/mg was used. }\end{array}$ & th a specific act & ivity of 550 \\
\hline & $\begin{array}{l}\text { Significantly differ } \\
\text { nonboiled enzyme. }\end{array}$ & nt from the $c$ & ase of the \\
\hline \multicolumn{4}{|c|}{$\begin{array}{l}\text { Significantly different from the case without } \\
\text { D-glucuronate. }\end{array}$} \\
\hline
\end{tabular}

Table 2. Susceptibility of ceftizoxime-treated E. coli to bactericidal action of hydrogen peroxide, hypochlorous acid and superoxide anion-generating system.

\begin{tabular}{cccc}
\hline \multirow{2}{*}{ Bactericidal materials } & Concentration & \multicolumn{2}{c}{ Viable E. coli ${ }^{\text {a }}(\%)$} \\
\cline { 3 - 4 } & $100 \mu \mu \mathrm{M}$ & Ceftizoxime-treated & Untreated \\
\hline Hydrogen peroxide & $200 \mu \mu \mathrm{M}$ & 38 & 70 \\
& $300 \mu \mu \mathrm{M}$ & 3.2 & 9.3 \\
Hypochlorous acid & $2.8 \mu \mathrm{M}$ & 0.2 & 2.4 \\
& $3.5 \mu \mathrm{M}$ & 8.0 & 58 \\
Xanthine oxidase & $0.05 \mathrm{U} / \mathrm{ml}$ & 20 & 42 \\
$\left(\mathrm{O}_{2}-\right.$ generating system) & $0.1 \mathrm{U} / \mathrm{ml}$ & 1.7 & 33 \\
& $0.2 \mathrm{U} / \mathrm{ml}$ & 0.8 & 6.1 \\
\hline
\end{tabular}

E. coli No. 59 was pretreated with ceftizoxime at 1/4 the MIC for 2 hours. Bactericidal test was done as described in Materials and Methods. All experiments were done in duplicate and the average values were shown.

a See legend to Fig. 3 .

$\beta$-glucuronidase killed the ceftizoxime-treated E. coli. Boiling the enzyme preparation and adding sodium D-glucuronate, a competitive inhibitor of $\beta$-glucuronidase, to this reaction mixture impaired the killing ability. Both the enzyme preparation with 32 -fold higher specific activity and the preparation mentioned above killed the ceftizoxime-treated $E$. coli (Table 1). These results indicate that the killing of ceftizoxime-treated $E$. coli by $\beta$-glucuronidase was due to the enzymatic activity of $\beta$ glucuronidase. However, the ceftizoxime-treated E. coli did not become more susceptible to the other lysosomal enzymes including lysozyme, acid phosphatase and phospholipase $\mathrm{A}_{2}$ (data not shown). 
Fig. 5. Morphological alteration of ceftizoximepretreated $E$. coli by $\beta$-glucuronidase.

E. coli No. 59 was pretreated with ceftizoxime at $1 / 16$ the MIC for 2 hours and treated with $\beta$ glucuronidase at $2,750 \mathrm{U} / \mathrm{ml}$. The morphology was observed with a scanning electron microscope.

A. Ceftizoxime-pretreated E. coli. B. Untreated E. coli. Bacteriolysis by the enzyme was observed in about $50 \%$ of ceftizoxime-pretreated $E$. coli but not in ceftizoxime-untreated $E$. coli.

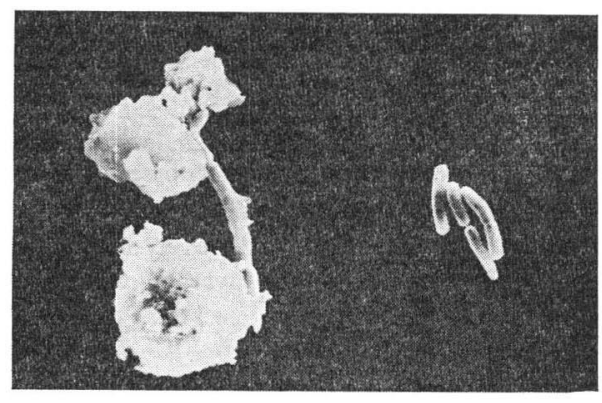

Table 3. Release of radioactivity from ceftizoximepretreated $\left[{ }^{3} \mathrm{H}\right]$ DAP-labeled $E$. coli after treatment with $\beta$-glucuronidase.

\begin{tabular}{lccc}
\hline \multirow{2}{*}{$\begin{array}{c}\text { Ceftizoxime } \\
\text { pretreatment }\end{array}$} & $\begin{array}{c}\beta \text {-Glucu- } \\
\text { ronidase } \\
\text { treatment }\end{array}$ & \multicolumn{2}{c}{ Release (\%) } \\
\cline { 3 - 4 } None & - & 27.6 & 24.3 \\
& + & 24.7 & 29.3 \\
1/16 MIC & - & 43.9 & 45.8 \\
& + & 55.5 & 71.1 \\
1/32 MIC & - & 39.4 & 40.3 \\
& + & 53.6 & 62.4 \\
\hline
\end{tabular}

E. coli No. 59 was labeled with $\left[{ }^{3} \mathrm{H}\right] \mathrm{DAP}$ as described in Materials and Methods, pretreated with ceftizoxime for 2 hours and treated with $\beta$ glucuronidase at $2,750 \mathrm{U} / \mathrm{ml}$. All experiments were done in duplicate and the average values are shown.

Next, the susceptibility of the ceftizoxime-treated $E$. coli to the bactericidal action of hydrogen peroxide and hypochlorous acid as a model of oxygen-dependent killing system of $\mathrm{PMNs}^{15)}$ was

compared with that of the untreated $E$. coli (Table 2). The ceftizoxime-treated $E$. coli became more susceptible than the untreated $E$. coli to the bactericidal activity of all of them.

Mode of Increased Susceptibility of Ceftizoxime-treated E. coli to $\beta$-Glucuronidase

The following additional studies were performed to clarify the mode of action of this most interesting aspect. Since treatment of the ceftizoxime-resistant $E$. coli No. 59R1 with ceftizoxime at $1 / 4$ the MIC for parent E. coli No. 59 did not increase the susceptibility to $\beta$-glucuronidase (data not shown), this phenomenon had to be due to the effect of ceftizoxime on E. coli. To elucidate the mode of the killing of the ceftizoxime-treated $E$. coli by $\beta$-glucuronidase, morphological changes of the bacteria were observed with a scanning electron microscope. The only change noted in the ceftizoximetreated $E$. coli was filamentation, however, incubation of the ceftizoxime-treated $E$. coli with $\beta$-glucuronidase induced bacteriolysis in about $50 \%$ of the population (Fig. 5A). In contrast, bacteriolysis did not occur in the untreated $E$. coli when incubated with the enzyme (Fig. 5B). Since the damage to peptidoglycan by the enzyme treatment can be thought as a background of the bacteriolysis, the degradation of peptidoglycan was estimated by measuring the release of radioactivity from E. coli labeled with $\left[{ }^{3} \mathrm{H}\right]$ DAP (Table 3 ). In the $E$. coli treated with $1 / 16$ and $1 / 32$ the MIC of ceftizoxime, the enzyme markedly increased the release of radioactivity, but only slightly in the ceftizoxime-untreated $E$. coli.

Next, to elucidate what ceftizoxime-induced damages to the bacterial surface the $\beta$-glucuronidasetriggered bacteriolysis was based on, the envelope damage by ceftizoxime was measured as described in Materials and Methods.

$\beta$-Lactamase was not leaked into the extracellular fluid of the ceftizoxime-treated $E$. coli No. 59R2 harboring the plasmid encoding TEM-type $\beta$-lactamase (Fig. 6). In contrast, ONPG with a much lower molecular weight than $\beta$-lactamase penetrated the envelope in the ceftizoxime-treated $E$. coli more easily than in the untreated E. coli (Table 4).

However, in this condition, the failure of viable cell counts in the ceftizoxime-treated $E$. coli to 
Fig. 6. Leakage of $\beta$-lactamase in ceftizoximetreated $E$. coli.

E. coli No. 59R2 producing TEM-type $\beta$ lactamase was obtained by transconjugation and pretreated with ceftizoxime at $1 / 4$ the MIC for 2 hours. The E. coli was incubated in a buffer $(\mathrm{pH}$ 6 ) and the $\beta$-lactamase activity of the supernatant was assayed using chromogenic cephalosporin.

* Relative enzyme activity of the supernatants to the respective total enzyme activity of sonicated E. coli.

Symbols: Untreated E. coli $(\bigcirc)$; ceftizoximepretreated E. coli ().

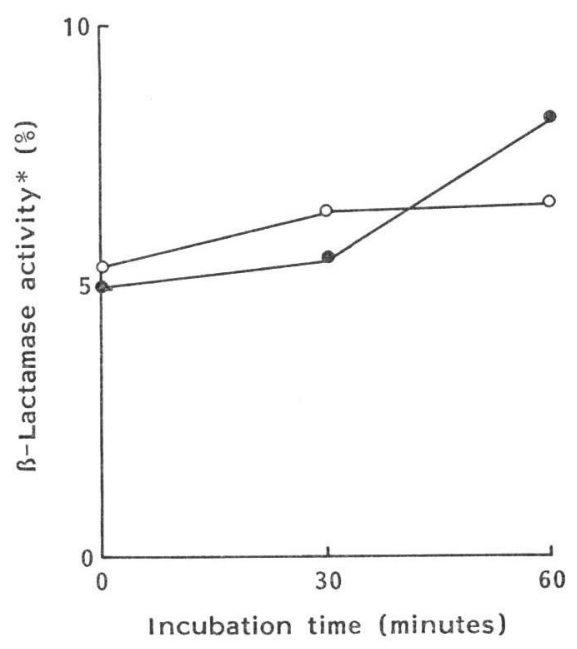

Table 4. Envelope permeability of ONPG in ceftizoxime-treated E. coli.

\begin{tabular}{lcc}
\hline $\begin{array}{c}\text { Ceftizoxime } \\
\text { pretreatment }\end{array}$ & $\begin{array}{c}\text { Envelope } \\
\text { permeability }(\%)^{\mathrm{a}}\end{array}$ & Viability $(\%)^{\mathrm{b}}$ \\
\hline None & 15 & 103 \\
$1 / 16 \mathrm{MIC}$ & 73 & 111 \\
$1 / 32 \mathrm{MIC}$ & 75 & 89 \\
\hline
\end{tabular}

Ceftizoxime-pretreated and untreated E. coli were incubated in buffer ( $\mathrm{pH} 6$ ) and the $\beta$-galactosidase activity and viable counts were measured as described in Materials and Methods.

a Percentage of $\beta$-galactosidase activity in intact E. coli compared with that in toluene-treated E. coli.

b Percentage of viable counts after incubation at pH 6 compared with those before incubation.

decrease suggests that the damage to the envelope was not lethal.

\section{Discussion}

The interaction of antimicrobial agents and PMNs in the killing of clinically important bacteria is an issue of considerable urgency. There have been many reports on this coopera$\operatorname{tion}^{1 \sim 9,16 \sim 19)}$, however, the mechanism of synergism has not been fully elucidated. Our previous studies on the interaction between antibiotics at sub-MIC and PMNs against $P$. aeruginosa have

shown that carbenicillin and sulbenicillin, which are inhibitors for the cell wall synthesis of bacteria, enhanced the phagocytic killing by PMNs, but colistin, polymyxin B, gentamicin and dibekacin, which have other modes of action, did not ${ }^{\theta)}$. The present study was designed to evaluate the synergism between the representative cephalosporins and PMNs, and the mode of action of this synergism.

Although there was some variation among the test agents in the extent of synergism, it is noteworthy that ceftizoxime, showed the most potent synergism with PMNs. That is; ceftizoxime enhanced the phagocytic killing of $E$. coli by PMNs at concentration as low as $1 / 32$ the MIC, and this tendency was confirmed in 3 replicate experiments. The variation among cephalosporins which have the same mechanism of action might be based on their different binding affinities to several essential penicillin binding proteins (PBPs). This synergism was caused by the increased susceptibility of $E$. coli to both phagocytosis and intracellular killing by PMNs, but not by direct enhancement of the PMN function by ceftizoxime. Furthermore, the strong synergistic effect of ceftizoxime and PMNs might be due to the increased susceptibility of the ceftizoxime-treated E. coli to the bactericidal activity of the granule extracts of PMNs, hydrogen peroxide, hypochlorous acid and $\mathrm{O}_{2}{ }^{-}$generating system as the models of oxygen-dependent and -independent killing systems of PMNs. It can be supposed that ceftizoxime greatly affects the bacterial surface structure by inhibiting cell wall synthesis. It is reported that the susceptibility of Gram-negative bacteria to the bactericidal materials of PMNs is related to the length of the saccharide chain of the lipopolysaccharides in the bacterial envelope ${ }^{20,21)}$. As shown in Table 3, the damage to the bacterial surface in the ceftizoxime-treated $E$. coli was not lethal, but the permeability barrier against the low molecular substance (ONPG) collapsed. This might explain why the ceftizoxime-treated $E$. coli was easily phagocytosed, killed and digested by the 
PMNs. PruUl et al. ${ }^{17 \sim 19)}$ reported that $E$. coli briefly pretreated with chloramphenicol at 4 times the MIC became more susceptible than the untreated E. coli to intracellular killing by PMNs and the bactericidal activity of the granule extract, but the bacteria pretreated with such $\beta$-lactams as ampicillin and cefoxitin did not. The discrepancies between our findings and theirs might be due to the different drugs and experimental conditions.

It is interesting that the ceftizoxime-treated $E$. coli became susceptible to $\beta$-glucuronidase, since this suggests that bacteria damaged by ceftizoxime can be effectively eliminated by $\beta$-glucuronidase in addition to well-known bactericidal substances such as active oxygen metabolites, myeloperoxidase and lysozyme. When the effect of ceftizoxime on the susceptibility to $\beta$-glucuronidase was compared with that of cephaloridine, mecillinam and cephalexin, which have high affinities to PBP 1, PBP 2 and PBP 3 respectively, the three drugs were less potent than ceftizoxime, which has a high affinity to both PBP 1 and PBP $3^{22)}$ (data not shown).

It is obvious that $\beta$-glucuronidase induced bacteriolysis in the ceftizoxime-treated $E$. coli by degrading peptidoglycan (Fig. 5 and Table 3). Since ceftizoxime did not induce the leakage of periplasmic $\beta$-lactamase (molecular weight: $25 \mathrm{~K}$ ) in E. coli, $\beta$-glucuronidase $(280 \mathrm{~K})$, which has higher molecular weight than $\beta$-lactamase, probably can not penetrate the periplasm to degrade the peptidoglycan. Alternatively, it is plausible that the enzyme could activate the autolytic enzyme degrading the peptidoglycan. GINSBURG ${ }^{1,23)}$ reported that autolytic enzymes took part in the killing of Staphylococcus aureus in lysosomes, and penicillins enhanced the enzyme activity. KITANO ${ }^{24)}$ suggests that the bactericidal activity of $\beta$-lactam antibiotics against $E$. coli is related to their affinity to PBP 1 and the activation of autolytic enzymes. From these findings, it can be supposed that pretreatment of $E$. coli with ceftizoxime at sub-MICs causes heavy but not lethal envelope damage and that the autolytic enzymes in the treated $E$. coli ready for activation were fully activated by $\beta$-glucuronidase-induced damage of the cell surface. However, it is difficult to ascertain the truth at present, because the regulation of the autolytic enzyme activity in Gram-negative bacteria is totally unknown, as well as the target sites of $\beta$-glucuronidase on the envelope of the damaged $E$. coli and the reactions which preceed bacteriolysis.

\section{References}

1) Efrati, C.; T. Sacks, N. Neeman, M. Lahav \& I. Ginsburg: The effect of leukocyte hydrolases on bacteria. VIII. The combined effect of leukocyte extract, lysozyme, enzyme "cocktails", and penicillin on the lysis of Staphylococcus aureus and group A streptococci in vitro. Inflammation 1: 371 407, 1976

2) Friedman, H. \& G. H. WARren: Antibody-mediated bacteriolysis: Enhanced killing of cyclacillin-treated bacteria. Proc. Soc. Exp. Biol. Med. 153: 301 304, 1976

3) FincH, R.: Immunomodulating effects of antimicrobial agents. J. Antimicrob. Chemother. 6: 691 694,1980

4) Lorian, V. \& B. AtKInson: Killing of oxacillin-exposed staphylococci in human polymorphonuclear leukocytes. Antimicrob. Agents Chemother. 18: 807 813, 1980

5) Gemmell, C. G.; P. K. Peterson, D. Schmeling, Y. Kim, J. Matews, L. Wannamaker \& P. G. Quie: Potentiation of opsonization and phagocytosis of Staphylococcus pyogenes following growth in the presence of clindamycin. J. Clin. Invest. 67: 1249 1256, 1981

6) TAYlor, P. W.; H. P. Kroll \& S. TOMLINSON: Effect of subinhibitory concentrations of mecillinam on expression of Escherichia coli surface components associated with serum resistance. Drugs Exptl. Clin. Res. 8: 625 631, 1982

7) LORIAN, V.: Effects of subminimum inhibitory concentrations of antibiotics on bacteria. In Antibiotics in Laboratory Medicine. Ed., V. LoRIAN, pp. 342 408, The Williams \& Wilkins Co., Baltimore, 1980

8) Nishida, M.; Y. Mine, S. Nonoyama \& Y. Yokota: Effect of antibiotics on the phagocytosis and killing of Pseudomonas aeruginosa by rabbit polymorphonuclear leukocytes. Chemotherapy (Basel) 22: 203 210,1976

9) Kamiya, T.; H. Aoki \& Y. Mine: Nocardicins. In Chemistry and Biology of $\beta$-Lactam Antibiotics. Ed., R. B. Morin \& M. Gorman, Vol. 2. pp. $165 \sim 226$, Academic Press, New York, 1982

10) COHN, Z. A. \& I. MORSE: Interaction between rabbit polymorphonuclear leukocytes and staphylococci. J. Exp. Med. 110: 419 443, 1959

11) Boyum, A.: Isolation of mononuclear cells and granulocytes from human blood. Scand. J. Clin. Labs. Invest. 21 (Suppl.): 77 89, 1962 
12) Rest, R. F.; M. H. Cooney \& J. K. Spintznagel: Bactericidal activity of specific and azulophil granules from human neutrophils: Studies with outer-membrane mutants of Salmonella typhymurium LT2. Infect. Immun. 19: 131 137, 1978

13) Reisngoud, D. J.; P. S. Oud, J. Kas \& J. TAger: Relationship between medium pH and that of the lysosomal matrix as studied by two independent methods. Biochim. Biophys. Acta 448: 290 302, 1976

14) Henning, R.: $\mathrm{pH}$ gradient across the lysosomal membrane generated by selective cation permeability and Donnan equilibrium. Biochim. Biophys. Acta 401: $307 \sim 316,1978$

15) Babior, B. M.; J. T. Curnnutte \& R. S. Kipnes: Biological defense mechanisms. Evidence for the participation of superoxide anion in bacterial killing by xanthine oxidase. J. Lab. Clin. Med. 85: 235 244, 1975

16) Milatovic, D.; I. Braveny \& J. Verohoef: Clindamycin enhances opsonization of Staphylococcus aureus. Antimicrob. Agents Chemother. 24: 413 417, 1983

17) Pruul, H. \& P. J. McDonald: Enhancement of leukocyte activity against Escherichia coli after brief exposure to chloramphenicol. Antimicrob. Agents Chemother. 16: 695 700, 1979

18) Pruul, H.; B. L. Wetherall \& P. J. McDonald: Enhanced susceptibility of Escherichia coli to intracellular killing by human polymorphonuclear leukocytes after in vitro incubation with chloramphenicol. Antimicrob. Agents Chemother. 19: 945 951, 1981

19) Pruul, H.; B. L. Wetherall \& P. J. McDonald: The susceptibility of antibiotic-pretreated bacteria to the bactericidal activity of human neutrophil granule extract. In The Influence of Antibiotics on the HostParasites Relationship. Ed., H.-U. EICKENBERG et al., pp. 208 218, Springer-Verlag, 1982

20) Friedberg, D. \& M. Shilo: Interaction of Gram-negative bacteria with the lysosomal fraction of polymorphonuclear leukocytes. I. Role of cell wall composition of Salmonella thyphymurium. Infect. Immun. 1: $305 \sim 310,1970$

21) Weiss, J.; S. Beckerdite-Quagliata \& P. Elsbach: Resistance of Gram-negative bacteria to purified bactericidal leukocyte proteins. J. Clin. Invest. 65: 619 628, 1980

22) Shigi, Y.; H. Kojo, M. Wakasugi \& M. Nishida: Differences between ceftizoxime and its stereoisomer in antibacterial activity and affinity for penicillin binding proteins. Antimicrob. Agents Chemother. 19: 393 396, 1981

23) Ginsburg, I.; M. Lahav \& P. Giesbrecht: Effect of leukocyte hydrolases on bacteria. XVI. Activation by leukocyte factors and cationic substances of autolytic enzymes in Staphylococcus aureus: Modulation by anionic polyelectrolytes in relation to survival of bacteria in inflammatory exudates. Inflammation 6 : 269 284, 1982

24) Kitano, K. \& A. Tomasz: Triggering of autolytic cell wall degradation in Escherichia coli by beta-lactam antibiotics. Antimicrob. Agents Chemother. 18: 838 848, 1979 